GRASAS Y ACEITES 71 (4)

October-December 2020, e376

ISSN-L: 0017-3495

https://doi.org/10.3989/gya.0795191

\title{
Influence of irrigation and fertilization on the sterol and triterpene dialcohol compositions of virgin olive oil
}

\author{
A. Arbonés ${ }^{\mathrm{a}}$, B. Sastre ${ }^{\mathrm{b}}$, M.A. Pérez ${ }^{\mathrm{b}}$, C. de Lorenzo ${ }^{\mathrm{b}}$, M. Pascual ${ }^{\mathrm{c}}$, A. Benito $^{\mathrm{b}}$, J.M. Villar ${ }^{\mathrm{d}}$ and \\ J. Rufat ${ }^{\mathrm{a}, \boldsymbol{M}}$ \\ ${ }^{a}$ Uso Eficiente del Agua en Agricultura. Instituto de Investigación y Tecnología Agroalimentaria IRTA. Lleida \\ ${ }^{b}$ Instituto Madrileño de Investigación y Desarrollo Rural, Agrario y AlimentarioIMIDRA \\ ${ }^{c}$ Departamento de Hortofruticultura Botánica y Jardinería. Universitat de Lleida \\ ${ }^{\mathrm{d}}$ Departamento de Medio Ambiente y Ciencias del Suelo. Universitat de Lleida \\ Corresponding author: josep.rufat@irta.cat
}

Submitted: 22 July 2019; Accepted: 04 October 2019; Published online: 05 October 2020

\begin{abstract}
SUMMARY: The objective of this work was to evaluate the influence of irrigation and fertilization with nitrogen and potassium on the sterol and triterpene dialcohol contents in two trials of cv. Arbequina in super-intensive orchards in Madrid and Lleida (Spain), using a completely randomized block design. No significant differences in total sterols between deficit and full irrigation treatments were observed. Under very dry conditions, the sterol levels from fully irrigated trees were higher than from rain-fed treatments and the triterpene dialcohol erythrodiol+ uvaol content was lower in the irrigated treatments in Lleida. In the fertilizer trial with full irrigation, total sterols were higher in the two $\mathrm{N}$ treatments compared to the unfertilized one; while erythrodiol + uvaol decreased. The application of $\mathrm{K}$ fertilizer had no effect on total sterol or triterpene dialcohol contents. A proper fertilization and irrigation are vital to obtain high quality EVOOs that meet the regulatory range in sterol and erythrodiol + uvaol contents.
\end{abstract}

KEYWORDS: Arbequina; Deficit irrigation; Erythrodiol + uvaol; Nitrogen; Potassium

RESUMEN: Influencia del riego y la fertilización en los esteroles y dialcoholes triterpénicos del aceite de oliva. El objetivo de este trabajo fue evaluar la influencia del riego y del abonado nitrogenado y potásico en los esteroles y los dialcoholes tritepénicos, en sendos ensayos de arbequina en superintensivo, con un diseño en bloques al azar, en Madrid y Lleida. No se observaron diferencias significativas de esteroles totales entre el riego deficitario y el riego completo. En condiciones de sequía extrema, los esteroles del riego completo fueron superiores al secano y los dialcoholes tritepénicos eritrodiol y uvaol fueron inferiores en los tratamientos de riego en Lleida. En el ensayo de abonado con riego completo, los esteroles totales fueron superiores en las dos aplicaciones de nitrógeno respecto al testigo no tratado y también disminuyeron el eritrodiol + uvaol. El abonado potásico no afectó a los esteroles totales ni a los dihalcoholes triterpénicos. Una fertilización y riego adecuados son de vital importancia para obtener AOVEs de alta calidad que cumplan con los límites legales del contenido en esteroles y eritrodiol + uvaol.

PALABRAS CLAVE: Arbequina; Eritrodiol + uvaol; Nitrógeno; Potasio; Riego deficitario

ORCID ID: Arbonés A https://orcid.org/0000-0001-8111-9449, Sastre B https://orcid.org/0000-0002-8300-7835, Pérez MA https://orcid.org/0000-0002-0196-1642, de Lorenzo C https://orcid.org/0000-0001-9846-509X, Pascual M https://orcid.org/0000-0002-3329-4207, Benito A https://orcid.org/0000-0002-2256-0899, Villar JM https://orcid. org/0000-0002-1068-8879, Rufat J https://orcid.org/0000-0002-7190-6147

Citation/Cómo citar este artículo: Arbonés A, Sastre B, Pérez MA, de Lorenzo C, Pascual M, Benito A, Villar JM, Rufat J. 2020. Influence of irrigation and fertilization on the sterol and triterpene dialcohol compositions of virgin olive oil. Grasas Aceites 71 (4), e376. https://doi.org/10.3989/gya.0795191

Copyright: (C2020 CSIC. This is an open-access article distributed under the terms of the Creative Commons Attribution 4.0 International (CC BY 4.0) License. 


\section{INTRODUCTION}

The content and composition of phytosterols are related to both oil quality and purity, with limits established in European and international regulations (EEC 2568/91; International Olive Council, 2016). These compounds are affected mainly by the variety (Kycyk et al., 2016; Guillaume et al., 2012) and maturity index of the olives (Gutiérrez et al., 1999; Fernández-Cuesta et al., 2013; Fuentes de Mendoza et al., 2013), as well as by the edaphoclimatic conditions of the plot and the characteristics of the harvest year (Aparicio and Luna, 2002; Uceda et al., 2008; Mailer et al., 2010). Post-harvest factors and the technological processes used in the oil production also have an influence (Guillaume et al., 2012).

In some cases, extra virgin olive oils (EVOO) have been found to not comply with these limits, though not because of a lack of purity but rather due to their intrinsic characteristics or agronomic management. Thus, the EVOO of the Cornicabra, Morrut, Corniche, Barnea and Benizal varieties exceed the statutory $4 \%$ of campesterol content (Salvador et al., 2001; Kycyk et al., 2016; Mailer et al., 2010). In some years, Empeltre oils have been found to exceed $0.6 \% \Delta$-7-stigmatenol (Gracia et al., 2009) and those of Cornezuelo the $0.5 \%$ cholesterol limit (Sánchez Casas et al., 2004). In other cases, the oils do not reach the minimum total sterol content of $1000 \mathrm{mg} \cdot \mathrm{kg}^{-1}$, as reported for the Benizal variety (Pardo et al., 2013); while Morrut did not reach the official limit 93\% requirement for apparent $\beta$-sitosterol (Kycyk et al., 2016).

Unlike the effect of variety and year on the composition of sterols, agronomic factors have been poorly studied (Rallo et al., 2018). The estimated heritability for concentrations of apparent $\beta$-sitosterol and $\Delta$-5-avenasterol shows low values at the beginning of olive maturation, indicating a high environmental influence on these characters at the beginning of fruit development (León et al., 2015).

In previous studies, the response to irrigation has not shown a clear trend. In an Arbequina trial in Aragón with three irrigation and one dry-land treatments, no significant differences were found in total sterol content or composition (Faci et al., 2002). In California, in a super-intensive trial of Arbequina with seven linearly increasing doses of water, irrigation showed positive effects on the sterols in extreme treatments, but with inconsistent results between years (Berenguer et al., 2006). However, in a trial in Victoria, Australia with three varieties and three irrigation levels in the period of oil accumulation it was observed that stigmasterol and $\Delta$-7-stigmatenol contents decreased with the highest irrigation application; while apparent $\beta$-sitosterol increased (Guillaume et al., 2012).
As for the effect of fertilization on sterols, no significant differences were observed in total sterols with the application of nitrogen and phosphorus in a rain-fed crop (Jordão et al., 2010), nor with foliar applications in an irrigated crop (Tekaya et al., 2013)

In addition, the levels of triterpene dialcohols erythrodiol and uvaol are clearly affected by the variety (Sánchez Casas et al., 2004) and processing conditions (Guillaume et al., 2012). The variety Verdial de Huevar has a high erythrodiol content (Aparicio and Luna 2002). Lechín de Granada, Cornicabra and Verdial de Badajoz (Allouche et al., 2009) have high erythrodiol and uvaol contents. In terms of irrigation treatments, a significantly higher erythrodiol content was observed with reduced irrigation doses in super-intensive Arbequina (Berenguer et al., 2006), although there were no differences with the deficit application during the oil accumulation period (Guillaume et al., 2012).

The objective of this study was to evaluate the influence of different irrigation treatments and the application of nitrogen and potassium on sterol composition and triterpene dialcohols erythrodiol + uvaol content in Arbequina virgin olive oil grown under super-intensive conditions.

\section{MATERIALS AND METHODS}

Irrigation and nutrition trials were initiated in Lleida in 2013, and irrigation trials in Madrid in 2014. This study presents the data from the oils obtained in 2015 and 2016 in Lleida and Madrid.

The Lleida trials were carried out in two plots in the Garrigues Denomination of Origin region: in a traditional Arbequina dry-land plantation in Maials, spaced $10 \times 10 \mathrm{~m} 100$ olive trees $\cdot \mathrm{ha}^{-1}$ and in a super-intensive plantation of Arbequina in Torres de Segre, Lleida, with spacing of $4.5 \times 2.2 \mathrm{~m}$ for 1010 olive trees ha $^{-1}$ (Rufat et al., 2014). The annual rainfall in 2015 was $249 \mathrm{~mm}\left(13 \mathrm{~mm}\right.$ from $1^{\text {st }}$ September to harvest), which is well below the average for the area of $350 \mathrm{~mm}$ and $383 \mathrm{~mm}$ in $2016(132 \mathrm{~mm}$ from $1^{\text {st }}$ September to harvest). Harvest dates were $23^{\text {rd }}$ October in 2015 and $29^{\text {th }}$ November in 2016. The soils are calcareous, loamy-silty textured, moderately deep and with a $1.5 \%$ organic matter content in Torres de Segre and loam textured with a 1.4\% organic matter content in Maials.

In the full irrigation treatment T-100, 100\% of the water needs throughout the year were met following the water balance method (Allen et al., 1998); while in the regulated deficit irrigation RDI- $0.440 \%$ of water needs were applied in July and August and $100 \%$ during the rest of the year. The T- 100 treatment was irrigated with an average of $4100 \mathrm{~m}^{3} \cdot \mathrm{ha}^{-1} \cdot \mathrm{year}^{-1}$ and the RDI-0.4 with $3210 \mathrm{~m}^{3} \cdot \mathrm{ha}^{-1} \cdot$ year $^{-1}$. The ET0, determined according to the Penman-Monteith 
method (Allen et al., 1998), was $1110 \mathrm{~mm}$ in 2015 and $1068 \mathrm{~mm}$ in 2016.

In the fertilizer trials in Torres de Segre, all treatments were fully irrigated (T-100) and four fertilizer treatments were applied: one without application of nitrogen or potassium $\mathrm{N}-0$, K-0; a second without nitrogen and with the application of $100 \mathrm{~kg} \cdot \mathrm{ha}^{-1}$ of potassium N-0, K-100; a third with $50 \mathrm{~kg} \cdot \mathrm{ha}^{-1}$ of nitrogen and $100 \mathrm{~kg} \cdot \mathrm{ha}^{-1}$ of potassium N-50, K-100; and a fourth with the application of $100 \mathrm{~kg} \cdot \mathrm{ha}^{-1}$ of nitrogen and 100 of potassium N-100, K-100. A randomized block design with four repetitions per treatment was used. Under the conditions of the Torres de Segre test, the annual average N contribution by the system mineralization, organic matter, irrigation water and rain amounted to $55 \mathrm{~kg}$ of $\mathrm{N} \cdot \mathrm{ha}^{-1} \cdot$ year $^{-1}$ (Belguerri et al., 2016).

The Madrid trial was located between the municipalities of Aranjuez and Colmenar de Oreja. The ET0 was 1334 and $1467 \mathrm{~mm}$ and the annual precipitation was $247 \mathrm{~mm}$ (36 mm from $1^{\text {st }}$ September to harvest) and $450 \mathrm{~mm}\left(80 \mathrm{~mm}\right.$ from $1^{\text {st }}$ September to harvest) in 2015 and 2016, respectively. The soil had $1 \%$ of organic matter, loam texture and limestone accumulation from $14 \mathrm{~cm}$. The same irrigation treatments were applied as in Torres de Segre: T-100 and RDI-0.4, in a super-intensive Arbequina plantation, with spacing of $3.75 \times 1.8 \mathrm{~m}$ for 1481 trees $\cdot \mathrm{ha}^{-1}$. The same experimental design was established as in Torres de Segre. The average irrigation water applied for T-100 and RDI-0.4 was 5280 and $3750 \mathrm{~m}^{3} \cdot \mathrm{ha}^{-1} \cdot$ year $^{-1}$.

Olive oil samples were obtained using the Abencor system (MC2 Ingenierias y Sistemas) and stored at $5^{\circ} \mathrm{C}$ for further analysis. The analyses of sterol composition and triterpene dialcoholserythrodiol and uvaol were performed by elementary plot, with three repetitions for each treatment, according to the official methods described in The European Commission Regulation 2568/91(EEC,1991). Only one sample for the treatment N-0, K-100 in 2016 could be analyzed.

The statistical analysis of the results was carried out using the JMP-SAS and SPSS 21 programs, using the Tukey test for the separation of means $p \leq 0.05$. Both ANOVA and multiple variance analyses (MANOVA) and simple linear regressions with the most important variables were performed.

\section{RESULTS}

\subsection{Effect of irrigation on composition of sterols and triterpene dialcohols}

The rain-fed fruits from the Lleida trials had a higher maturity index than those from the irrigated treatments. In Lleida, olives were harvested on October $23^{\text {rd }}$ with a maturity index above 3.5 , which was very high for Arbequina and one month ahead of the usual date. In Madrid, harvesting took place on October $26^{\text {th }}$ with a maturity index of 3.4. The 2016 season had a high crop load in Lleida, with harvesting taking place on November $29^{\text {th }}$ with a maturity index of 1.4 in the irrigated and 2.5 in the rain-fed treatments. Harvesting in Madrid was on November $7^{\text {th }}$ with a maturity index of 3.0 (Table 1). Significant differences were found in total sterol content in Lleida in 2015, which was a very dry year, especially in the period of oil accumulation. The rain-fed oil had $25 \%$ less sterols than the T-100. For the rest of the trials and years, there were no significant differences.

The sterol composition of the oils from Lleida was only affected for stigmasterol in 2015 (Table 1), showing higher values for irrigated than rain-fed treatments. This trend was maintained in 2016. For campestanol, the contents were significantly higher in the rain-fed treatments in 2016, though no differences were found in 2015. Campesterol levels in Madrid in 2015 were significantly higher in the RDI0.4 than in the T-100 treatments; while the content of apparent $\beta$-sitosterol was higher in T-100 than in RDI-0.4. In both cases in 2016, there were no significant differences. The rest of the percentages in the composition of regulated sterols did not present significant differences in any of the locations.

The triterpene dialcohols, in Lleida in 2015, decreased significantly in the two irrigation treatments compared to the rain-fed one. There were no significant differences between the two irrigation treatments. The percentages of uvaol and erythrodiol followed the same trend with irrigation in both Madrid and Lleida in 2016 (Table 1).

\subsection{Effect of nitrogen and potassium on sterol composition and triterpene dialcohols}

The results of this trial by year, $\mathrm{N}$ and $\mathrm{K}$ doses are presented in Table 2. Leaf nitrogen, phosphorus and potassium contents were adequate. In the case of leaf $\mathrm{N}$ content, higher values were obtained from the $\mathrm{N}$ application treatments.

The results of the MANOVA, with the levels of $\mathrm{N}, \mathrm{K}$ and year as independent variables, are shown in Table 3. No significant differences were obtained for the maturity index between treatments, although it was higher in 2015. Pearson's correlations were made between maturity index and total and sterol compounds. There was only a significant correlation among the maturity index with total sterols $(r=0.566, p=0.009)$; with apparent $\beta$-sitosterol $(r=-0.497, p=0.026)$; and with $\Delta 7$-Avenasterol $(\mathrm{r}=0.729, \mathrm{p}=0.001)$.

The treatments with $\mathrm{N}$ application $\mathrm{N}-50$ and $\mathrm{N}-100$ contained about $25 \%$ more total sterols than the treatment without $\mathrm{N}$ application $\mathrm{N}-0$, with no 


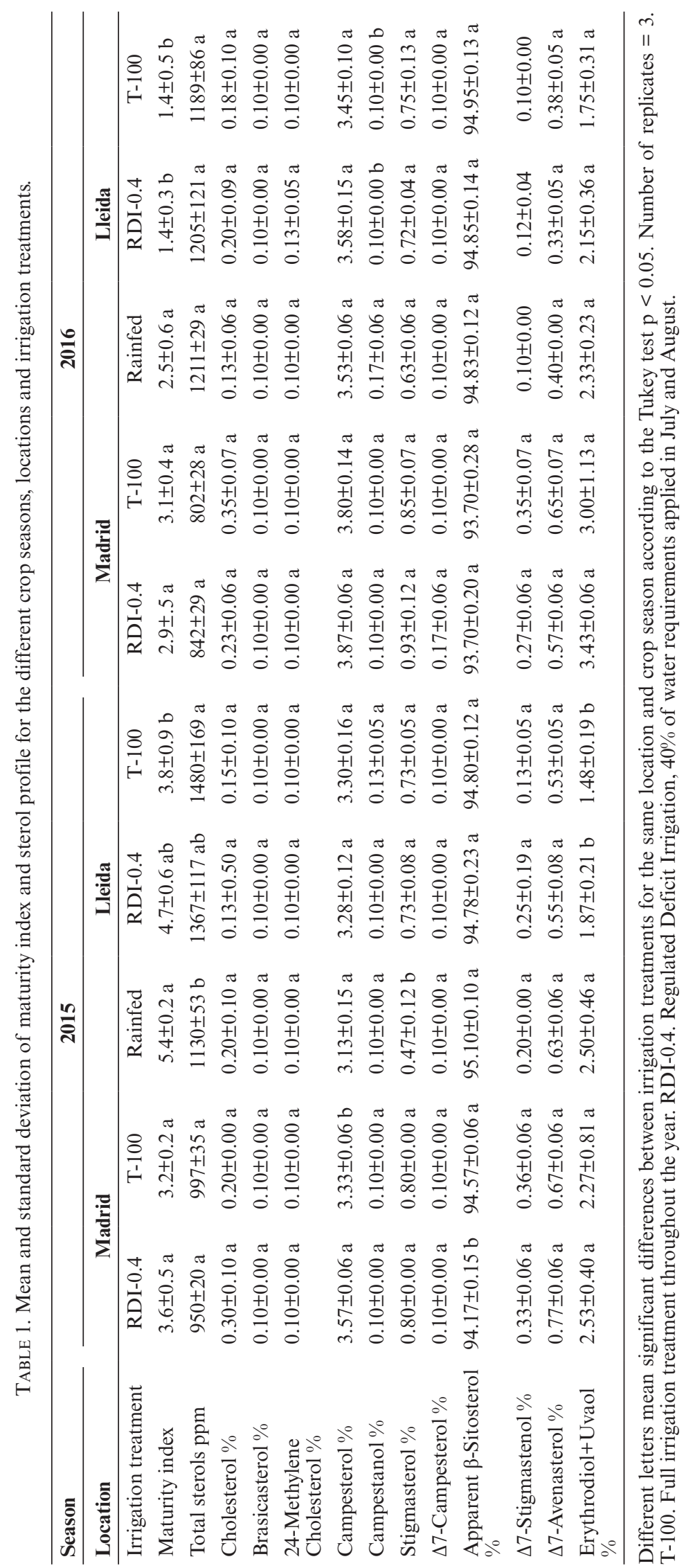


TABLE 2. Mean and standard deviation of maturity index, leaf macronutrients and sterol profile for the different crop seasons and fertilization doses. Lleida. Years 2015-2016.

\begin{tabular}{|c|c|c|c|c|c|c|c|c|}
\hline \multirow{3}{*}{$\begin{array}{l}\mathrm{N} \text { dose } \\
\mathrm{K} \text { dose }\end{array}$} & \multicolumn{4}{|c|}{2015} & \multicolumn{4}{|c|}{2016} \\
\hline & \multicolumn{2}{|c|}{0} & \multirow{2}{*}{$\begin{array}{c}50 \\
100\end{array}$} & \multirow{2}{*}{$\begin{array}{l}100 \\
100\end{array}$} & \multicolumn{2}{|l|}{0} & \multirow{2}{*}{$\begin{array}{c}50 \\
100\end{array}$} & \multirow{2}{*}{$\begin{array}{l}100 \\
100\end{array}$} \\
\hline & 0 & 100 & & & 0 & 100 & & \\
\hline Maturity index & $4.5 \pm 0.2$ & $3.2 \pm 0.9$ & $4.8 \pm 1.2$ & $4.5 \pm 0.9$ & $1.5 \pm 0.4$ & 0.8 & $1.9 \pm 0.5$ & $2.2 \pm 0.9$ \\
\hline \multicolumn{9}{|l|}{ Leaf nutrients } \\
\hline $\mathrm{N} \%$ & $1.77 \pm 0.08$ & $1.82 \pm 0.13$ & $2.09 \pm 0.03$ & $2.12 \pm 0.06$ & $1.55 \pm 0.09$ & 1.54 & $2.37 \pm 0.09$ & $2.25 \pm 0.10$ \\
\hline $\mathrm{P} \%$ & $0.27 \pm 0.01$ & $0.26 \pm 0.02$ & $0.19 \pm 0.01$ & $0.19 \pm 0.01$ & $0.18 \pm 0.03$ & 0.18 & $0.18 \pm 0.02$ & $0.17 \pm 0.02$ \\
\hline $\mathrm{K} \%$ & $1.41 \pm 0.08$ & $1.54 \pm 0.10$ & $1.43 \pm 0.04$ & $1.38 \pm 0.04$ & $1.32 \pm 0.12$ & 1.45 & $1.36 \pm 0.05$ & $1.25 \pm 0.05$ \\
\hline \multicolumn{9}{|c|}{ Sterol and triterpene dialcohol content } \\
\hline Total sterols ppm & $1507 \pm 262$ & $1453 \pm 120$ & $1770 \pm 48$ & $1748 \pm 18$ & $1170 \pm 94$ & 1245 & $1622 \pm 103$ & $1568 \pm 139$ \\
\hline Cholesterol \% & $0.20 \pm 0.14$ & $0.10 \pm 0.00$ & $0.13 \pm 0.06$ & $0.10 \pm 0.00$ & $0.20 \pm 0.10$ & 0.10 & $0.17 \pm 0.06$ & $0.13 \pm 0.06$ \\
\hline Brasicasterol $\%$ & $0.10 \pm 0.00$ & $0.10 \pm 0.00$ & $0.10 \pm 0.00$ & $0.10 \pm 0.00$ & $0.10 \pm 0.00$ & 0.10 & $0.10 \pm 0.00$ & $0.10 \pm 0.00$ \\
\hline 24-Methylene cholesterol $\%$ & $0.13 \pm 0.06$ & $0.10 \pm 0.00$ & $0.10 \pm 0.00$ & $0.10 \pm 0.00$ & $0.10 \pm 0.00$ & 0.10 & $0.10 \pm 0.00$ & $0.13 \pm 0.06$ \\
\hline Campesterol \% & $3.30 \pm 0.00$ & $3.30 \pm 0.28$ & $3.70 \pm 0.17$ & $3.53 \pm 0.12$ & $3.43 \pm 0.12$ & 3.50 & $3.77 \pm 0.06$ & $3.67 \pm 0.15$ \\
\hline Campestanol \% & $0.15 \pm 0.07$ & $0.10 \pm 0.00$ & $0.10 \pm 0.00$ & $0.10 \pm 0.00$ & $0.10 \pm 0.00$ & 0.10 & $0.10 \pm 0.00$ & $0.10 \pm 0.00$ \\
\hline Stigmasterol \% & $0.70 \pm 0.00$ & $0.75 \pm 0.07$ & $0.77 \pm 0.06$ & $0.80 \pm 0.10$ & $0.73 \pm 0.15$ & 0.80 & $0.80 \pm 0.00$ & $0.80 \pm 0.00$ \\
\hline$\Delta 7$-Campesterol \% & $0.10 \pm 0.00$ & $0.10 \pm 0.00$ & $0.13 \pm 0.06$ & $0.10 \pm 0.00$ & $0.10 \pm 0.00$ & 0.10 & $0.10 \pm 0.00$ & $0.10 \pm 0.00$ \\
\hline Apparent $\beta$-Sitosterol \% & $94.80 \pm 0.14$ & $94.80 \pm 0.14$ & $94.43 \pm 0.21$ & $94.57 \pm 0.06$ & $94.97 \pm 0.15$ & 94.90 & $94.63 \pm 0.23$ & $94.80 \pm 0.10$ \\
\hline$\Delta 7$-Stigmastenol $\%$ & $0.15 \pm 0.07$ & $0.10 \pm 0.00$ & $0.13 \pm 0.06$ & $0.13 \pm 0.06$ & $0.10 \pm 0.00$ & 0.10 & $0.10 \pm 0.00$ & $0.10 \pm 0.00$ \\
\hline$\Delta 7$-Avenasterol $\%$ & $0.50 \pm 0.00$ & $0.55 \pm 0.07$ & $0.50 \pm 0.00$ & $0.53 \pm 0.06$ & $0.37 \pm 0.06$ & 0.40 & $0.30 \pm 0.00$ & $0.30 \pm 0.00$ \\
\hline Erythrodiol+Uvaol \% & $1.60 \pm 0.00$ & $1.35 \pm 0.21$ & $1.23 \pm 0.12$ & $1.33 \pm 0.12$ & $1.70 \pm 0.36$ & 1.90 & $1.03 \pm 0.12$ & $1.43 \pm 0.23$ \\
\hline
\end{tabular}

$\mathrm{N}=0,50$ and $100 \mathrm{~kg}$ of Nitrogen $\cdot \mathrm{ha}^{-1} \cdot \mathrm{year}^{-1}$

$\mathrm{K}=0$ and $100 \mathrm{~kg}$ of Potassium $\cdot \mathrm{ha}^{-1} \cdot \mathrm{year}^{-1}$

Number of replicates $=3$.

significant differences between the application of $50 \mathrm{~kg} \cdot \mathrm{ha}^{-1}$ and $100 \mathrm{~kg} \cdot \mathrm{ha}^{-1}$ of $\mathrm{N}$. The campesterol content was $6-10 \%$ higher in the treatments with $\mathrm{N}$ application than the N-0 treatment. There were no variations in the other sterol compositions.

The application of $\mathrm{N}$ decreased the percentage of erythrodiol + uvaol compared to the N-0 treatment, with no significant differences among $\mathrm{N}$ treatments.

The application of potassium had no effect on the studied variables.

The oils had a significantly higher total sterol content in 2015 than in 2016. There were significant differences between years in the apparent $\beta$-sitosterol and $\Delta 7$-Avenasterol values, with the first increasing and the second decreasing in 2016. No differences between years were obtained for the other sterols or the erythrodiol + uvaol values.

Due to the important effect that $\mathrm{N}$ had on total sterol contents and on erythrodiol + uvaol percentages, correlations were found between leaf $\mathrm{N}$ and these parameters. A strong positive linear correlation $\left(\mathrm{R}^{2}=0.76\right)$ was obtained between total sterol content and the percentage of leaf N (Figure 1). The correlation between the leaf $\mathrm{N}$ and erythrodiol + uvaol values showed the opposite trend $\left(\mathrm{R}^{2}=0.53\right)$ (Figure 2).

\section{DISCUSSION}

No significant differences were obtained in the maturity index among fertilization treatments within the same year. The total sterol content was higher in 2015, possibly due to a higher maturity index at harvest, in accordance with other works in which higher total sterols were obtained as the maturation status progressed (León et al., 2015), slowing down on the final dates (Fernández-Cuesta et al., 2013).

\subsection{Effect of irrigation on sterols and triterpene dialcohols}

The results of the response of the irrigation treatments are in agreement with those of Berenguer et al., (2006) in a super-intensive trial of Arbequina in California. They observed an increase in total sterols with irrigation between the extreme treatments, but not in the intermediate situations. This concurs with the findings of the present study in which differences were found between the T-100 and the rain-fed orchard in Lleida in 2015, a very dry year with only $13.4 \mathrm{~mm}$ rainfall in September and October, which was much lower than the average. However, our findings differ from the results of an Arbequina trial in 


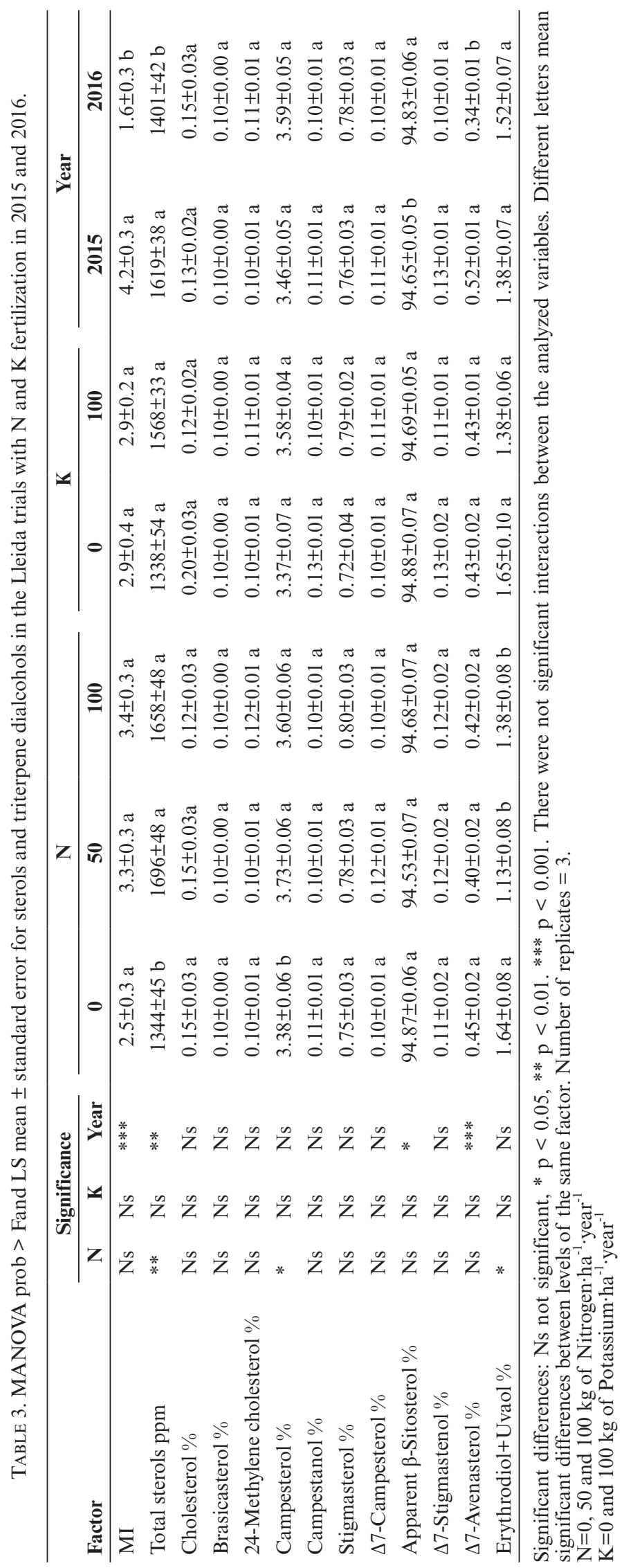




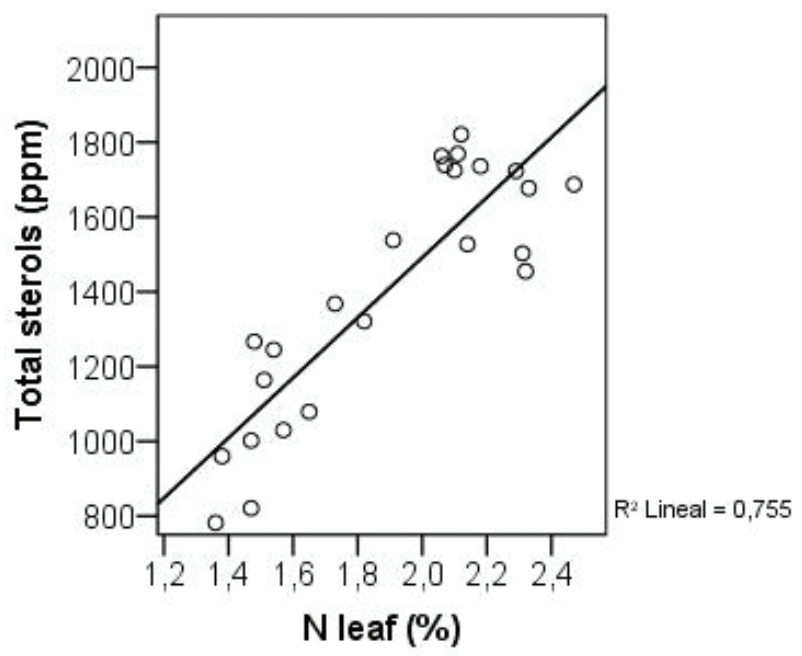

FIGURE 1. Linear regression between leaf $\mathrm{N}$ content and total sterols $\left(\mathrm{R}^{2}=0.76\right)$ considering all test samples in both campaigns. Number of replicates $=3$.

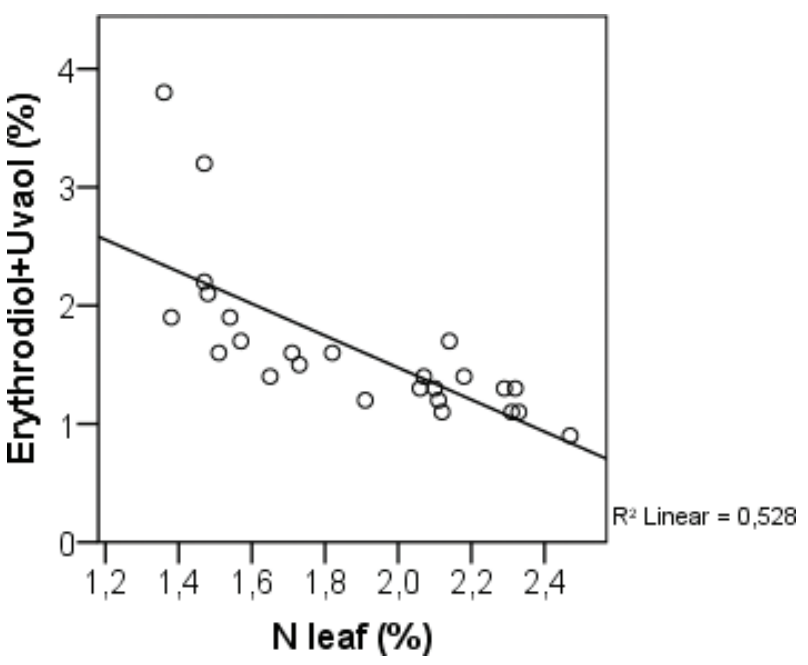

FIGURE 2. Linear regression between leaf $\mathrm{N}$ content and triterpene dialcohols $\left(\mathrm{R}^{2}=0.53\right)$ considering all test samples in both campaigns. Number of replicates $=3$.

Aragón in which it was concluded that irrigation treatments did not affect total sterol content or its composition (Faci et al., 2002). Vita Serman et al., (2011) also failed to find a clear relationship between total sterols and the level of water stress. In contrast, Fernández Silva et al., (2013) and Stefanoudaki et al., (2001) observed that total sterols decreased with irrigation in the Cobrançosa and Koroneiki varieties, respectively. In general, there was no consistent trend between years and locations for any of the compounds studied in relation to irrigation.

Regarding the sterol profile, the decrease in campesterol with the increase in irrigation in Madrid in 2015 was consistent with that observed by
Berenguer et al., (2006), which, if confirmed, could be positive for varieties that are at the regulatory limit of content in campesterol. The most important quantitative component in the group of sterols is $\beta$-sitosterol, which together with $\Delta$-5-avenasterol and other minor sterols (chelosterol, sitostanol, $\Delta$-5,24-stigmastedienol and $\Delta$-5,23-stigmastedienol), are the components of apparent $\beta$-sitosterol, and by regulation, should be greater than $93 \%$ in virgin olive oils.

In 2015, oil from rainfed treatments had a lower content of stigmasterol compared to the irrigation treatments, with the same trend observed in 2016. Although the increase in this phytosterol is not 
positive, that values would be widely within the more restrictive international regulations. These results are in agreement with those reported by FernandesSilva et al., (2013) in northeast Portugal, with an average annual rainfall of $520 \mathrm{~mm}$. Although campestanol showed a significant decrease in the rainfed treatment in 2016, the opposite trend was observed in the previous year and so the results were inconclusive. In a trial with the Carolea variety in southern Italy (annual rainfall of $480 \mathrm{~mm}$ ), which compared high deficit irrigation, only $80 \mathrm{~mm}$ of irrigation water applied, and rainfed conditions, decreases in the content of campesterol, apparent $\beta$-sitosterol and $\Delta$-5-avenasterol were observed in the irrigated treatment (Inglese et al., 1996).

In the Lleida trial, oil from rainfed trees had significantly more triterpene dialcohols than the irrigated ones in 2015, a particularly dry year. Similarly, Berenguer et al., (2006) observed a decrease in the erythrodiol content with increasing irrigation in the most extreme treatments of $15 \%$ ETc and $107 \%$ ETc.

This inconsistency of results between years for sterol contents, as also pointed out in other studies (Berenguer et al., 2006), shows that other variables may be more relevant than water stress for these parameters.

\subsection{Effect of fertilization on sterol and triterpenic dialcohol contents}

The application of different $\mathrm{N}$ or $\mathrm{K}$ doses did not affect the maturity index between treatments within each year. Total sterols increased significantly with the application of N. This relationship was not observed by Jordão et al., (2010) in a rainfed trial with the Verdeal Transmontana variety in Mirandela Portugal (annual rainfall ranged from 265-769 mm during the trial) or by Tekaya et al., (2013) in a trial with foliar applications of fertilizers under irrigation in Tunisia $(400 \mathrm{~mm}$ of annual rainfall) with the Picholine variety. In the present work, an increase was also observed in campesterol with the application of $\mathrm{N}$, without exceeding the regulatory limit, something that was not found in the work of Tekaya et al., (2013). However, this group reported an increase in apparent $\beta$-sitosterol for the treatment with urea in addition to boron, magnesium, manganese and sulfur with respect to the untreated control, and a reduction in the erythrodiol+uvaol content in the urea treatment with trace elements compared to the untreated control. The nitrogen fertilizer increased the content of total sterols and this was essential for all olive oils, especially for varieties in which genuine oils fall outside regulation limits.

Although in all the treatments of the Lleida trial the leaf $\mathrm{N}$ values were within the range of sufficiency of $1.5-2.5 \%$, the increase in $\mathrm{N}$ fertilization doses increased total sterols by $25 \%$ and decreased erythrodiol+uvaol content in the Arbequina variety by $23 \%$. The influence of irrigation level on the nutritional status of olive trees seemed to depend strongly on the variety. This raises the question of whether the reference values used today can be applied indiscriminately to all varieties, especially in intensive irrigated plantations (Zipori et al., 2015).

In the correlation of leaf $\mathrm{N}$ with total sterols in the Madrid and Lleida trials, a linear increase in total sterol content was obtained with leaf $\mathrm{N}$ content. It was also observed that the sterol content could be lower than $1000 \mathrm{mg} \cdot \mathrm{kg}^{-1}$ for leaf $\mathrm{N}$ content below $1.5 \%$ in the Arbequina variety (Fig.1), which in this case is below the minimum level required in the Commission Delegated Regulation (EU) 2016/2095.

A negative correlation was obtained between triterpenic dialcohols (erythrodiol+uvaol) and leaf $\mathrm{N}$ content, although in this case the levels were within those established for EVOOs (less than 4.5\%).

The correct $\mathrm{N}$ fertilization management of varieties with low levels of total sterols or high percentages of triterpene dialcohols could ensure that the resulting oils do not exceed the limits established in EVOO regulations.

The application of $\mathrm{K}$ fertilizer in the $\mathrm{K}-100$ treatment had no effect on the maturity index when compared to the untreated control in either 2015 or 2016. The application of $\mathrm{K}$ in Arbequina with leaf levels higher than $1.2 \%$ had no effect on sterol or triterpene dialcohol contents. In this respect, Erel et al., $(2013,2018)$ also concluded that the application of $\mathrm{K}$ fertilizer had a negligible effect on oil quality.

\section{CONCLUSIONS}

The effect of $\mathrm{N}$ fertilization on the content and profile of sterols and triterpene dialcohols in extra virgin olive oils was more evident than the effect of irrigation. Fertilization with $\mathrm{K}$ did not affect these compounds under the conditions of this study.

The application of $\mathrm{N}$ increased total sterol content in the oils, with a linear correlation obtained between leaf $\mathrm{N}$ content of the olive trees and total sterol content of the oils. Virgin olive oils obtained from Arbequina trees with a leaf $\mathrm{N}$ content below the $1.5 \%$ threshold could have a total sterol content lower than the legal limit of $1000 \mathrm{mg} \cdot \mathrm{kg}^{-1}$. The application of $\mathrm{N}$ reduced triterpene dialcohol erythrodiol+uvaol content regardless of the applied dose, with a linear correlation also obtained between these variables. In this case, a low leaf $\mathrm{N}$ content did not imply that the erythrodiol+uvaol content should be higher than the threshold limit established in the corresponding regulations.

An irrigation effect was observed mainly in 2015, a dry year, especially at the time of oil synthesis.

The results of this work are of relevance considering that nutritional or water stress problems in the olive grove could lead to the resulting EVOOs 
falling outside the regulatory range in sterol and erythrodiol+uvaol contents.

\section{ACKNOWLEDGEMENTS}

This work was funded in part by the project RTA2012-00059 of the INIA (Spanish Ministry of Economy and Competitiveness).

\section{REFERENCES}

Allen RG, Pereira LS, Raes D, Smith M. 1998. Crop Evapotranspiration: Guidelines for computing crop water requirements -FAO Irrigation and drainage paper 56.

Allouche Y, Jiménez A, Uceda M, Paz Aguilera M, Gaforio JJ, Beltrán G. 2009. Triterpenic content and chemometric analysis of virgin olive oils from forty olive cultivars. $J$. Agric. Food Chem. 57, 3604-3610. https://doi.org/10.1021/ jf $803237 \mathrm{z}$

Aparicio R, Luna G. 2002. Characterisation of monovarietal virgin olive oils. Eur. J. Lipid Sci. and Technol. 104, 614-627. https:// doi.org/10.1002/1438-9312(200210)104:9/10<614::AIDEJLT614>3.0.CO;2-L

Belguerri H, Villar JM, Pascual M, Fatmi A, Amadeu A, Rufat J. 2016. A proposal of nitrogen balance in a very highdensity olive orchard. J. Fundament. App. Sci. 8, 639-654. https://doi.org/10.4314/jfas.v8i2.30

Berenguer MJ, Vossen PM, Grattan SR, Connell JH, Polito VS. 2006. Tree irrigation levels for optimum chemical and sensory properties of olive oil. Hort Sci. 41, 427-432. https:// doi.org/10.21273/HORTSCI.41.2.427

Commission Regulation EEC No 2568/91 of 11 July 1991 on the characteristics of olive oil and olive-residue oil and on the relevant methods of analysis.

Erel R, Kerem Z, Ben-Gal A, Dag A, Schwartz A, Zipori I, Basheer L, Yermiyahu U. 2013. Olive Oleaeuropaea L. tree nitrogen status is a key factor for olive oil quality. J. Agric. Food Chem.61, 112 61-11272. https://doi.org/10.1021/jf4031585

Erel R, Yermiyhu Y, Ben-Gal A, Dag A. 2018. Olive fertilization under intensive cultivation management. Acta Hortic. 1217, 207-224. https://doi.org/10.17660/ActaHortic.2018.1217.27

Faci JM, Berenguer MJ, Espada JL, Gracia S.2002. Effect of variable water irrigation supply in olive Olea europaea L. cv. arbequina in Aragon Spain II. Extra Virgin Oil Quality Parameters. Acta Hortic. 586, 649-652. https://doi. org/10.17660/ActaHortic.2002.586.138

Fernández-Cuesta A, León L, Velasco L, De la Rosa R. 2013. Changes in squalene and sterols associated with olive maturation. Food Res. Internat. 54, 1885-1889. https://doi. org/10.1016/j.foodres.2013.07.049

Fernandes-Silva AA, Gouveia JB, Vasconcelos P, Ferreira TC, Villalobos FJ. 2013. Effect of different irrigation regimes on the quality attributes of monovarietal virgin olive oil from cv. Cobrançosa. Grasas Aceites 64, 41-49. https://doi. org/10.3989/gya.070512

Fuentes de Mendoza M, De Miguel C, Marín J, Sánchez J, Martínez M, Martín D, Franco MN. 2013. Chemical composition of virgin olive oils according to the ripening in olives. Food Chem. 141, 2575-2581. https://doi. org/10.1016/j.foodchem.2013.05.074

Gracia MS, Roy A, Guillén M. 2009. Chemical composition of olive oils from Arbequina and Empeltre varieties grown in irrigation. Grasas Aceites 60, 321-329. https://doi. org/10.3989/gya.097008

Guillaume C, Ravetti L, Ray DL. Johnson J. 2012. Technological factors affecting sterols in Australian olive oils. J. Am. Oil Chem. Soc. 89, 29-39. https://doi.org/10.1007/ s11746-011-1883-Z

Gutiérrez F, Jiménez B, Ruíz A, Albi MA. 1999. Effect of olive ripeness on the oxidative stability of virgin olive oil extracted from the varieties Picual and Hojiblanca and on the different components involved. J. Agric. Food Chem. 47, 121-127.

Inglese P, Barone E, Gullo G. 1996. The effect of complementary irrigation on fruit growth, ripening pattern and oil characteristics of olive Olea europaea L. cv. Carolea. J. Hortic. Sci. 71, 257-263.

International Olive Council. 2015. Trade Standard Applying to Olive Oils and Olive-Pomace Oils COI/T.15/NC No 3/Rev. 9 June.

Jordão PV, Encarnaçao Marcelo M, Lopes JI, Simoes Lopes P. 2010. A long-term experiment on olive tree with nitrogen, phosphorus and limestone fertilization. VI International Symposium on Mineral Nutrition of Fruit Crops 868, 313318. https://doi.org/10.17660/ActaHortic.2010.868.41

Kycyk O, Aguilera MP, Gaforio J, Jimenez A, Beltran G. 2016. Sterol composition of virgin olive oil of forty-three olive cultivars from the World Collection Olive Germplasm Bank of Cordoba. J. Sci. Food Agric. 96, 4143-4150. https://doi.org/10.1002/jsfa.7616

León L, Velasco L, de la Rosa R. 2015. Initial selection steps in olive breeding programs. Euphytica 201, 453-462. https:// doi.org/10.1007/s10681-014-1232-z

Mailer RJ, Ayton J, Graham K. 2010. The influence of growing region, cultivar and harvest timing on the diversity of Australian olive oil. J. Am. Oil Chem. Soc. 87, 877-884. https://doi.org/10.1007/s11746-010-1608-8

Pardo JE, Sena E, Cuesta MA, Granell JD, Valiente J, ÁlvarezOrtí M. 2013. Evaluation of potential and real quality of virgin olive oil from "Campos de Hellín" Albacete, Spain. J. Am. Oil Chem. Soc. 90, 851-862. https://doi.org/10.1007/ s11746-013-2222-3

RalloL, Díez CM, Morales-Sillero A, Miho H, Priego-Capote F, Rallo P. 2018. Quality of olives: A focus on agricultural preharvest factors. Scientia Hortic. 233, 491-509. https:// doi.org/10.1016/j.scienta.2017.12.034

Rufat J, Villar JM, Pascual M, FalgueraV, Arbonés A. 2014. Productive and vegetative response to different irrigation and fertilization strategies of an Arbequina olive orchard grown under super-intensive conditions. Agric. Water Manage. 144, 33-41

Salvador MD, Aranda F, Fregapane G. 2001. Influence of fruit ripening on 'Cornicabra' virgin olive oil quality - A study of four successive crop seasons. Food Chem. 73, 45-53. https://doi.org/10.1016/S0308-8146(00)00276-4

Sánchez Casas J, Bueno EO, Garcia AMM, Cano MM. 2004. Sterol and erythrodiol + uvaol content of virgin olive oils from cultivars of Extremadura Spain. Food Chem. 87, 225-230. https://doi.org/10.1016/j.foodchem.2003.11.012

Stefanoudaki E, Chartzoulakis K, Kotsafakis A, Kotsifaki F. 2001. Effect of drought stress on qualitative characteristics of olive oil of cv. Koroneiki. Grasas Aceites 5, 202-206

Tekaya M, Mechri B, Bchir A. Attia F, Cheheb H, Daassa M, Hammami A. 2013. Effect of nutrient-based fertilisers of olive trees on olive oil quality. J. Sci. Food Agric. 93, 2045-2052. https://doi.org/10.1002/jsfa.6015

Uceda M, Hermoso M, Aguilera MP 2008. La calidad del aceite de oliva. p. 699-727. In: D. Barranco R. FernándezEscobar and L. Rallo eds., El cultivo del olivo, Ediciones Mundi-Prensa y Junta de Andalucía, Madrid.

Velasco L, De la Rosa R, León L. 2015. Advanced olive selections with enhanced quality for minor constituents. Grasas Aceites 66 (4) e100. https://doi.org/10.3989/ gya. 0227151

Vita Serman F, Pacheco D, Carelli A, Capraro F. 2011. Effect of regulated deficit irrigation strategies on productivity, quality and water use efficiency in a high-density 'Arbequina' olive orchard located in an arid region of Argentina. Acta Hortic. 888, 81-88. https://doi.org/10.17660/ ActaHortic.2011.888.8

Zipori I, Yemeanyahu U, Ere IR, Presnov E, Faingold I, Ben-Gal A, Dag A. 2015. The influence of irrigation level on olive tree nutritional status. Irrig. Sci. 33, 277-287. 